\title{
Research on the Competitive Advantages of Movie- Television Cultural and Creative Enterprises in Guangdong-Hong Kong-Macao Greater Bay Area
}

\author{
Chuan Hsiu $\mathrm{Ho}^{1, *}$ \\ ${ }^{1}$ School of Literature, Zhaoqing University, Zhaoqing, Guangdong, China \\ *Corresponding author. Email: dericho@zqu.edu.cn
}

\begin{abstract}
The current national policy strongly supports the development of the Guangdong-Hong Kong-Macao Greater Bay Area. Therefore, how can Lingnan film and television works meet the consumers' needs under the global market competition, promote the positive energy, improve the quality, and then promote the culture and art of the whole area moving towards a new realm becomes the most important issues. If Lingnan movie-television companies want to have the lasting competitive advantages, they must understand their own resources and capabilities to obtain them. This study cited the theory of competitive advantage, using literature analysis and secondary data analysis, and found three unique competitive advantages for Lingnan movie-television cultural and creative enterprises in the Greater Bay Area: the first is the innovation of the content of movie-television works, the second is the rich content of movie-television creation to satisfy consumer demand, and the third is that Lingnan movie-television cultural and creative enterprises in the Greater Bay Area welcome and apply technology heartedly. The movie-television cultural and creative industry in the Greater Bay Area can accelerate the sustainable development of the competitiveness through content innovation and industrial policy management.
\end{abstract}

Keywords: Guangdong-Hong Kong-Macao Greater Bay Area, Movie-television cultural and creative enterprises, Competitive advantage.

\section{INTRODUCTION}

On February 18, 2019, the State Council of China issued the "Guangdong-Hong Kong-Macao Greater Bay Area Development Plan Outline". This programmatic document plans the overall situation, with science as the cornerstone and culture as the foundation, and is of great significance for the coordinated and cooperative development of the Guangdong-Hong Kong-Macao Greater Bay Area. Together with the "Guangdong-Hong Kong-Macao Art and Cultural Cooperation Agreement" signed in August 2003, Guangdong, Hong Kong and Macao have obtained rich collaborative achievements in movie-television programs, talents exchanging, cultural communication, and promotion of Lingnan arts and cultural industry development research.

At present, the movie-television cultural and creative industry has entered the era of digital technology, and has been forcibly digitized, forcing the creation and production of the movie-television cultural and creative industries to transform. The production of film and television has been twisted to larger or smaller, or reduced production, making the movie-television industry enter to the winterly low operating situation. Especially in recent years, the movie-television box office has changed from rapid growth to decline, and the rating keeps in a downturn; on the other hand, the crisis of trust caused by the problem of taxation of movietelevision practitioners has caused the production market to be sluggish; furthermore, with the difficulty of financing the movie-television industry, the sharp decline in the market value of listed companies, and the large withdrawal of movie-television cultural and creative capital, the movie industry is facing major competition challenges. 
Therefore, it is a must to understand its own resources and capabilities in order to obtain and furthermore improve a lasting competitive advantage in the Lingnan movie-television cultural and creative industry in the Greater Bay Area.

\section{RESEARCH ON THE COMPETITIVE ADVANTAGES OF MOVIE-TELEVISION CULTURAL AND CREATIVE ENTERPRISES}

Competitive advantage has become the research direction of industrial competition strategy thinking in recent years. Since the global economy has been intensified since the rise of the community economy, scholars started to think about how companies can increase their competitiveness in the continuously changing market environment. The business operating and strategic researching models are proposed to help us understand the enterprise sustainable competitive advantage. This study summarizes the relevant research findings in the past 30 years, and found the three main theories to discuss the competitive advantage of enterprises as follows:

\subsection{Resource-based View (RBV)}

Since the 1990s, the resource-based view (RBV) has been used to explain the relationship between the characteristics of a company's resources and its lasting competitive advantage [1], but it is not sufficient to fully explain that today's companies are committed to alliances with external partners and knowledge acquisition. The cultural and creative industries that have emerged in recent years can effectively supplement the deficiencies of traditional RBV. The important resources needed for business operations may exceed the definition of enterprises. The complementarity of exclusive assets and resources between alliance partners can be helpful to improve competitive advantage of cultural and creative industries.

\subsection{Competence-based View (CBV)}

Prahadra and Hamel first put forward the basic viewpoint of competence. The basic competence theory mainly describes: "Competence is the cumulative effect of collective learning, especially learning how to coordinate scattered production technologies and integrate diverse technologies, and involves the transfer of an organization's operating system and its own value." [3]. Under this concept, competence becomes an extended result of the organization's collective learning of multiple assets and ability combinations.

Therefore, as far as the cultural and creative movie-television industry is concerned, a movietelevision company is a fairly diversified enterprise that produces a variety of audio and video products to serve the public market in order to gain more audiences' support, higher box office, or viewing rates.

\subsection{Dynamic Capability View (DCV)}

With the advent of the globalization era, the boundaries and goals of business operations have become blurred and change rapidly, coupled with the shortening of the product life cycle (PLC), for many companies, the most effective way to compete is often unknown. Therefore, scholars started to discuss that in the process of the development and extension of corporate competitive advantages, the concept of dynamics was confirmed [4].

Therefore, on the whole, it's a must to develop gradually the dynamic capabilities embedded in enterprise to adapt to changes. For example, as the cultural and creative movie-television industry is facing a rapidly changing market for consumption content, audio-visual content related enterprises must reinforce the application of technology and creative innovation in scripts in order to keep up with.

Take an overview on these theories and we can see a certain degree of relevance among them. According to theoretical logical inference, it's common that the latter theory often brought up to make up for the shortcomings of the previous theoretical viewpoints, but after careful inferences, we still will find that there are several similar points of view and differences as well. Therefore, this study believes that these three points of view are not mutually exclusive results, and on the contrary, these three theories have mutual affiliation and have further extended effects.

Therefore, the cultural and creative movietelevision industry needs to add a dynamic, continuity, and adjustment point of view in the face of a rapidly competitive market environment, that is, cultural and creative audio-visual related enterprises should possess dynamic capabilities, so that they have the driving force to withstand changes and be able to adapt environmental changes, and even more be able to predict changes of market and advance toward the changings. In 
this way, a relatively complete structure of the competitive advantage of audio-visual cultural enterprises can be formed, that is, the "sustainable" competitive advantage of audio-visual cultural enterprises called in this study.

\section{RESEARCH ON THE COMPETITIVE ADVANTAGES OF MOVIE-TELEVISION CULTURAL AND CREATIVE ENTERPRISES}

Lingnan area has a good humanistic environment and rich cultural resources. Different from the traditional Chinese inland cultural, the Lingnan culture, which includes Cantonese culture, Hakka culture, Chaoshan culture and other branches, was nurtured in an open and diverse marine cultural background. The Lingnan culture after the Chinese economic reform and opening up is even more brilliant, especially the proposing of "Guangdong spirit", which is based on the essence of the Lingnan culture, combined with the spirit of the reform and opening up, to establish a new image of openness, pragmatism, compatibility and pioneering [5]. It also transforms the energy of humanistic environment and cultural resources into new capabilities of Lingnan movie-television cultural and creative enterprises.

This research uses qualitative analysis in main. Discover the competitive advantages of Lingnan movie-television cultural enterprises through the literature analysis method, and use the secondary data analysis method to collect and analyze the information from the in-depth interviews of scholars, experts and practitioners related to movietelevision culture. Through the cross comparison of literature analysis and secondary data analysis, this research attempts to deeply deconstruct the competitive advantage model of Lingnan movietelevision cultural enterprises, and provides a strategic suggestion for promoting movie-television cultural creativity and innovation.

The core competitiveness model of Lingnan movie-television enterprises is guided by the competitive advantages of movie- television content, plus the elements: content creativity with consumers as the core; organizational innovation with the purpose of a learning organization; human resources with talent development as the core; marketing innovation with the brand as the core, all together constitutes a virtuous cycle of competitive advantage model. And all activities in the model are aimed at realizing the competitive advantage of
Lingnan cultural and creative movie-television enterprises in the Greater Bay Area ("Figure 1").

It's needed to establish consumer-centric values as the goal through starting from the consumer's point of view, and constantly improving and accumulating consumer value; it's also necessary to identify target consumers, explore potential consumers, create content value, and enhance the core competitiveness of movie-television enterprises; organizational innovation with the purpose of a learning organization is accomplished by continuously acquiring knowledge, using knowledge, and creating knowledge to improve organizational performance. Human resources with talent development as the core are to ensure the smooth development of the learning organizations, make employees to have unique and exclusive knowledge and skills, and guarantee consumer value; finally, marketing innovation with the brand as the core enables the promotion of corporate value, and the guarantee of consumer value, thus maintaining the advantage of the core competitiveness of movie-television enterprises. The four elements guided by the management model build up a virtuous circle to ensure the realization of the core values of the enterprise. 


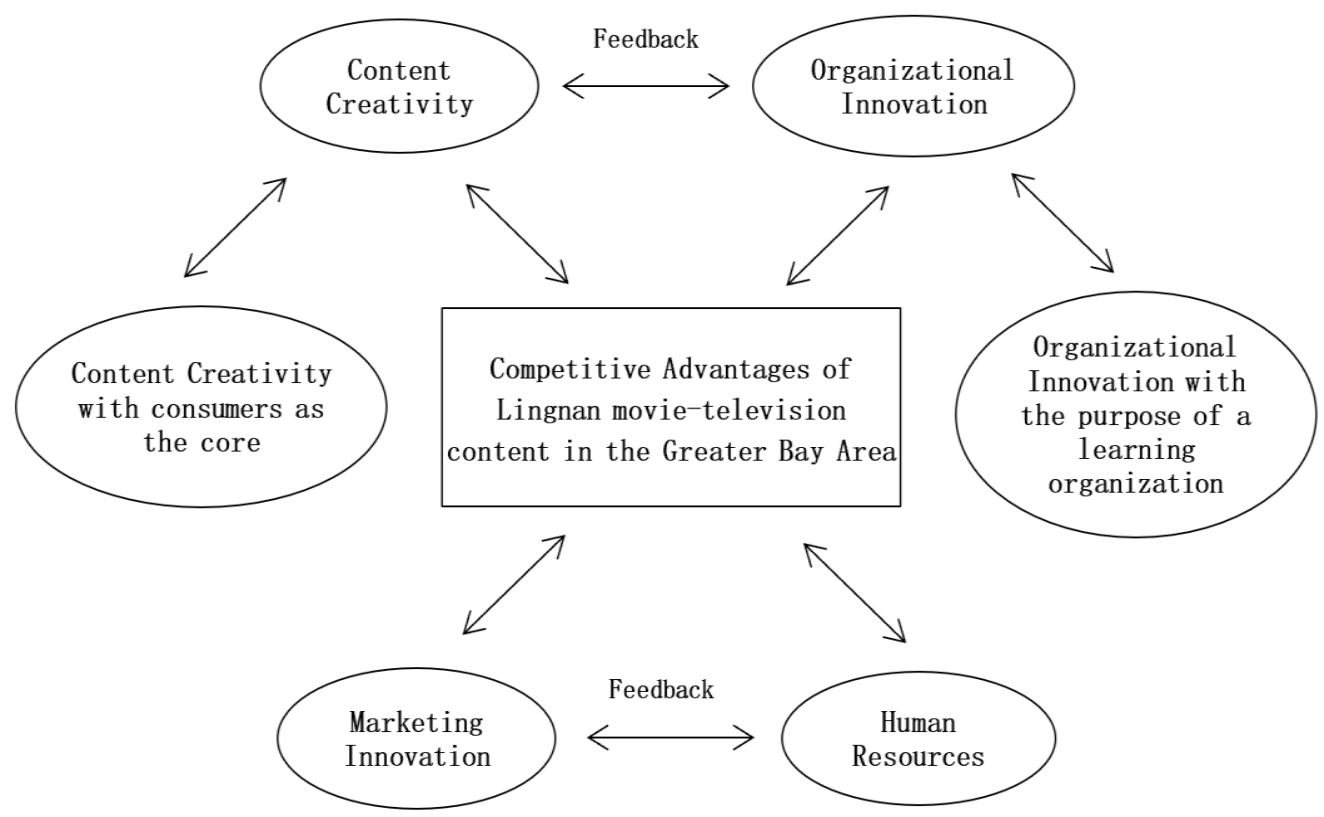

Figure 1 Competitive advantage model of Lingnan movie-television cultural and creative enterprises in the Greater Bay Area.

\section{UNIQUE COMPETITIVE ADVANTAGES OF LINGNAN MOVIE-TELEVISION CULTURAL AND CREATIVE ENTERPRISES IN THE GREATER BAY AREA}

This research is based on the secondary data method and the literature analysis method, including the laws and regulations, policies and other documents of the Lingnan movie-television cultural and creative enterprises in the Greater Bay Area, important speeches by relevant department leaders, directors, and other related books, periodicals, reviews and networks Data etc. In the researching process, the Lingnan movie-television cultural and creative enterprises in the Greater Bay Area were the main body, and the theoretical viewpoint of corporate competitive advantage was adopted to construct the competitive advantage model, and then through the cross comparison to discover the unique competitive advantages of Lingnan movie-television cultural and creative enterprises in the Greater Bay Area.

Therefore, it can be observed that Lingnan movie-television cultural and creative enterprises have three important unique advantages in the face of the uncertain competition in the audio-visual cultural and creative content market:

\subsection{Innovation in the Content of Lingnan Movie-Television Works in the Greater Bay Area}

This study observed that Lingnan's drama product content, due to the pressure of the audience-oriented market and filming costs, started from heroic movies, zombie series movies, kung fu movies, Stephen Chow comedy movies, etc., and gathered a group of supporters of Greater Bay Area movies. And furthermore, in order to strive for a broad consumer population of film and television, it keeps learning new forms and expression skills of film and television in Europe and the United States. Therefore, various audio-visual cultural and creative enterprises in Lingnan have also invested more to develop new themes and technologies to maintain their competitive advantage.

\subsection{Consumer Needs Satisfied by Various and Rich Creative Themes of Greater Bay Area Lingnan Movie-Television}

The changes in the technological age have made most Lingnan audio-visual enterprises to adopt big data to understand consumer' needs and preference. Therefore, big data has a profound impact on the production mechanism of audio-visual enterprises in the Greater Bay Area, such as production, content planning and market feedback evaluation, etc., to provide production basis. Therefore, audio- 
visual cultural and creative enterprises in the Greater Bay Area mostly are using big data to determine users' needs and hobbies, and hence develop movie-television products which accurately aim the target users, promoting the taste and precision of movie-television content, continuously strengthening the audiences' experience, and realizing a win-win situation for platform operators, viewers, and content production companies.

\subsection{Greater Bay Area Lingnan Movie- Television Cultural and Creative Enterprises Embrace Technology}

The most important thing in the production innovation of audio-visual cultural and creative products is not only the innovation of content thinking, but also to replace it with "product innovation thinking", and make it fully-used on creative thinking and new technology in $R \& D$ and production technology, insight into the tastes of the viewing population and creative research and development, optimize planning and production processes, and improve the production efficiency and the ability to innovate audio-visual content products.

\section{CONCLUSION}

In the era of audio-visual technology, especially for the Lingnan cultural consumers in the Greater Bay Area, whose economic strength ranks first or two among the whole country, in addition to receiving huge productions of movie-television cultural and creative products, consumers in the Greater Bay Area have higher requirements for them. [6] Therefore, if all Lingnan movie-television cultural and creative enterprises and teams in the Greater Bay Area want to remain invincible in the fierce competition for the viewing rate of movietelevision works, they must improve the creative quality of the movie-television cultural and creative industry, especially the originality of movietelevision cultural and creative works. Only by using rich creative content to continuously subvert old-fashioned expressions and give consumers a sense of freshness and surprise, can the movietelevision cultural and creative works truly be recognized by the Lingnan consumer market in the Greater Bay Area, and hence be improved and upgrade their soft power and the competitive advantage of Lingnan movie-television products in the Greater Bay Area.

\section{AUTHORS' CONTRIBUTIONS}

This paper is independently completed by Chuan Hsiu Ho.

\section{REFERENCES}

[1] J. Barney, Firm Resources and Sustained Competitive Advantage. Journal of Management [J], 17, 99-120, 1991.

[2] D. Lavie, "The Competitive Advantage of Interconnected Firms: An Extension of the Resource-Based View". Academy of Management Review [J], 31,638-658,2006.

[3] C.K. Prahalad, Garry Hamel, "The Core Competence of the Corporation", Harvard Business Review [J], No.90311,March-April,1992.

[4] D.Leonard-Barton, "Core capabilities and core rigidities: A paradox in managing new product development". Strategic management journal [J], 13, 111-125, 1992.

[5] Weijun Chen, Consolidate the cultural heritage of the Greater Bay Area with Lingnan Culture [J]. People's Forum. 2019-19.

[6] Bi Jiaqi. Promoting the in-depth exchange and cooperation of Guangdong-Hong KongMacao film and television works [N]. Nanfang Daily, 2019-03-19. 